\title{
Biologically Synthesized Silver Nanoparticles for Enhancing Tetracycline Activity Against Staphylococcus aureus and Klebsiella pneumoniae
}

\author{
Elsayed Alsaied Masoud Hussein ${ }^{1,2^{*}}$ \\ http://orcid.org/0000-0003-3723-2887
}

\author{
Ali Al-Hajry Mohammad ${ }^{3}$ \\ https://orcid.org/0000-0003-0403-637X \\ Farid Abourageh Harraz 3 ,4 \\ https://orcid.org/0000-0001-7776-7099 \\ Mohd Faisal Ahsan ${ }^{3}$ \\ https://orcid.org/0000-0002-9054-1710
}

\begin{abstract}
${ }^{1}$ Najran University, Community College, Department of Microbiology, Saudi Arabia, Najran; ${ }^{2}$ Animal Health Research Institute, Egypt, Giza, Dokki; ${ }^{3}$ Promising Centre for Sensors and Electronic Devices (PCSED), Advanced Materials and Nano-Research Centre, Saudi Arabia, Najran, Najran University; ${ }^{4}$ Nanostructured Materials and Nanotechnology Division, Central Metallurgical Research and Development Institute (CMRDI), Egypt, Cairo, Helwan.
\end{abstract}

Received: 2018.05.26; Accepted: 2019.07.08.

${ }^{*}$ Correspondence: e-mail: husseinea1968@yahoo.com; Tel.: $00966559165572-00201011846465$ (E.A.M.H)

\section{HIGHLIGHTS}

- Interest in nanoparticles has attracted our attention toward applications in managing bacterial diseases.

- Significant differences between the tested plant extracts in supporting AgNPs synthesis.

- AgNPs synthesized by ginger showed the highest antibacterial activity.

- AgNPs significantly enhanced tetracycline activity against tested bacteria.

Abstract: Phytochemical content of plant extracts can be used effectively to reduce the metal ions to nanoparticles in one-step green synthesis process. In this study, six plant extracts were used for the synthesis of silver nanoparticles (AgNPs). Biologically synthesized AgNPs was characterized using UV-Vis Spectrophotometer, Field Emission Scanning Electron Microscope (FE-SEM), X-ray diffraction (XRD), Energy Dispersive X-ray spectroscopy (EDX) and Fourier Transform Infrared (FTIR) spectroscopy. The individual and combined effects of AgNPs and tetracycline against $S$. aureus and $K$. pneumoniae were 
assessed. Ginger, onion and sidr extracts supported AgNPs formation while arak, garlic and mint extracts failed to convert the silver ions to AgNPs. The present findings revealed significant differences between the tested plant extracts in supporting AgNPs synthesis. AgNPs synthesized by ginger showed the highest individual and combined activity against tested strains followed by AgNPs prepared by sidr then that synthesized by onion. AgNPs significantly enhanced tetracycline activity $(p \leq 0.05)$ against $S$. aureus and $K$. pneumoniae. The results of this study demonstrated that the combination of tetracycline and biologically synthesized AgNPs presented a useful therapeutically method for the treatment of bacterial infection and counterattacking bacterial resistance.

Keywords: Silver nanoparticles; Biosynthesis; Plant extracts; Tetracycline; S. aureus; K. pneumoniae.

\section{INTRODUCTION}

Abuse of antibiotics and chemical bactericides have resulted in development of resistant bacterial strains, which in turn creates the onset of infectious diseases [1, 2]. Staphylococcus aureus and Klebsiella pneumoniae are major resistant bacterial pathogens that can induce life-threatening diseases [3-5]. To limit such resistance, researchers are looking for alternatives antimicrobial agent $[6,7]$. Recently, nanotechnology became part of our daily life and the social and economic impact of nanotechnological developments is being recognized [8]. Up till now, several aspects of applications of the nanoscience, in the fields including cosmetics, novel materials manufacturing, medicine and pharmaceutics are unknown [9]. In the last decade, the medicinal applications of nanotechnology are significantly increased, which leads to raising hopes for using the nanoparticles as alternative antimicrobial agents. Significant development in synthesis of nanoparticles has attracted researchers' attention toward applications in managing bacterial diseases [10]. Due to their antibacterial activities, silver compounds are used to prevent skin infections, such as burns and as coating on different surfaces such as catheters $[11,12]$. Nanoparticles can be synthesized by physical, chemical and biological methods. Preparation of nanoparticles via conventional chemical and physical methods results in toxic byproducts that have environmental hazards. These nanoparticles cannot be employed in medicine especially in clinical fields due to health-related issues [13, 14]. Biological methods are costeffective, eco-friendly and rely on the use of plant extracts, enzymes and microorganisms [15]. Interestingly, the synthesis of AgNPs using plant extracts is a rapid process compared with the synthesis using bacteria or fungi [16]. Although several studies have demonstrated the antibacterial activity of AgNPs, studies of the combination of AgNPs and antibiotics are warranted. Tetracyclines are often used in the treatment of infections of respiratory tract, urinary tract and intestinal tract, and are also used in the treatment of chlamydia, especially in patients allergic to macrolides and $\beta$-lactams. Using of tetracycline for these indications is decreased due to increased microbial resistance. The most common current use of tetracycline is in the treatment of acne and rosacea [17]. Tetracyclines remain the drug of choice for treatment of rickettsia, chlamydia, spirochetal and brucellosis infections. Additionally, they may be used for the treatment of tularemia, plague, anthrax and cholera disease [18]. The combination of nanoparticles and antibiotics could increase the antibiotics' efficiency against resistant microorganisms [19, 20]. Antibiotic-nanoparticle conjugates decrease the dosage of both agents, which lower the noxiousness and increase the antimicrobial efficacy [21,22].The main objective of the current study is to refine and compare the bio-synthesis of AgNPs using various plant extracts and to evaluate the individual and in combination activity of AgNPs prepared by different extracts and tetracycline against Staphylococcus aureus and Klebsiella pneumonia 


\section{MATERIAL AND METHODS}

\section{Collection of plants}

Six plants were used in the current study, Salvadora persica [arak], Allium sativum [garlic], Allium cepa [onion], Zingiber officinale [ginger], Mentha spicata [mint] and Ziziphus spina- Christi [sidr]. Healthy leaves of arak and sidr were collected from trees distributed in Najran region, Saudi Arabia. Bulbs of garlic and onion, ginger roots and mint were purchased from local markets in Najran city. Najran is located in the south part of Saudi Arabia, along the border with Yemen.

\section{Optimization of silver nanoparticles}

Silver nitrate [AgNO3, 99.995\%] was purchased from VWR. The optimization process was carried out for obtaining better synthesis of AgNPs. The parameters employed in the optimization process were plant type [6 plants], plant concentrations [10, 20 and $25 \mathrm{gm} /$ $100 \mathrm{~mL}$ distilled water] and heating time of aqueous plant extracts [2, 5 and 10 minutes]. Also, the effects of heating temperature of plant extracts $\left[80,100^{\circ} \mathrm{C}\right]$, silver ion concentrations [1 $1 \mathrm{mM}, 2 \mathrm{mM}$ ] and percentage of plant extract to silver ion [10, $20 \mathrm{~mL} / 90 \mathrm{~mL}$ of AgNO3] and incubation time [24, 48 hours.] were tested. Fresh healthy leaves of arak, mint, sidr, and bulb of garlic, bulb of onion and rhizome of ginger were washed 4 times in tap water followed by distilled water then dried and cut into fine pieces and crushed by mortar and pestle. $100 \mathrm{ml}$ distilled water was added into the fine pieces of the crushed plants then heated, sieved and filtrated by using Whatman filter paper No. 1(Fig.1). The filtrated plant extracts were kept in refrigerator until use. After addition of plant extracts to the silver ions, the change in the color of the solution was observed and the absorbance was measured spectrophotometrically. Plant extracts were prepared at Microbiology laboratory, College of Pharmacy, Najran University.

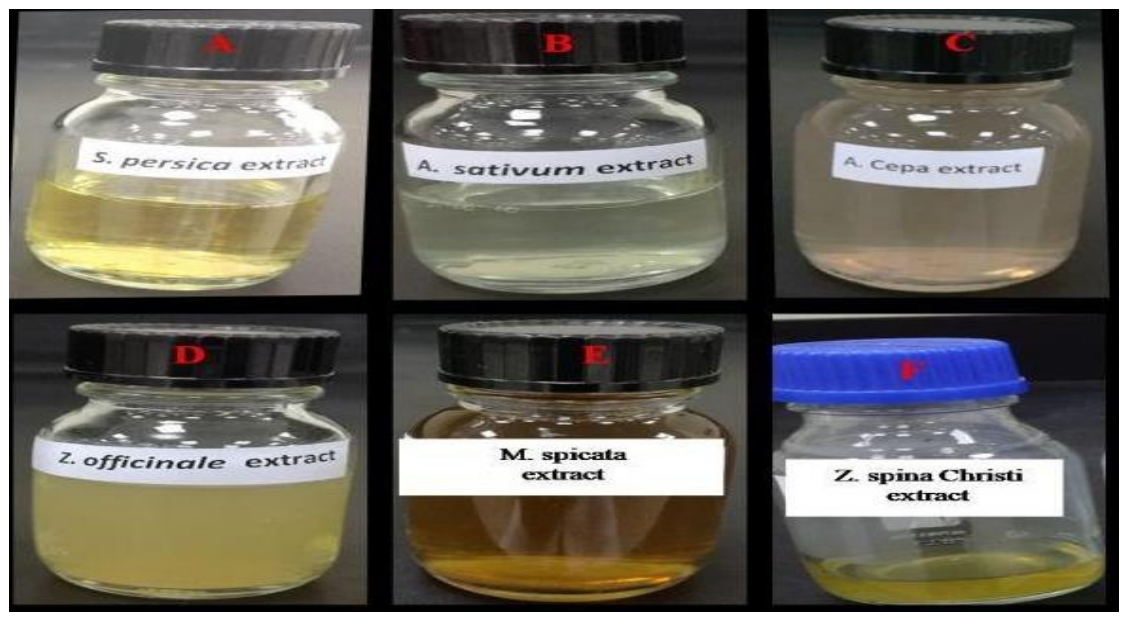

Figure 1. Plant extracts.

\section{Characterization of as-synthesized AgNPs}

The characterization and confirmation of silver nanoparticles synthesis was conducted at Advanced Materials and Nano-Research Centre, Najran University, Saudi Arabia. UV-Vis spectra were conducted in the range of 200 to $800 \mathrm{~nm}$ using Perkin Elmer-Lambda 950-UV-visible spectrometer. The crystal structure and phase formed for as-synthesized AgNPs were examined by X-ray powder diffraction (XRD) using a BRUKER D8 advance with $\mathrm{Cu}$ target $(\lambda 1.54 \AA)$. The diffraction patterns were collected at $40 \mathrm{kV}$ and $40 \mathrm{~mA}$, with a $0.05^{\circ}$ step size and a count time of $3 \mathrm{~s}$. Morphological analysis of as-synthesized AgNPs was examined using FESEM (QUANTA FEG 250) equipped with energy dispersive X-ray spectroscopy (EDX). Fourier transforms infrared (FT-IR) spectra were collected at a spatial resolution of $4 \mathrm{~cm}-1$ in the transmission mode, in the range of 400 to $4000 \mathrm{~cm}-1$ using Perkin Elmer spectrophotometer. The samples were prepared using the $\mathrm{KBr}$ pellet technique and 
were analyzed to examine the surface chemistry of the reduced AgNPs as well as the presence of biofunctional moieties of plant extracts.

\section{Antibacterial activity of AgNPs and tetracycline}

For testing antibacterial activity, $S$. aureus (Gram-positive) and K. pneumoniae (Gram-negative) were attained from the laboratory of Microbiology, Najran University Hospital, Najran region, Saudi Arabia. The isolates were identified an automatically (Micro Scan Walkaway, Siemens) and the results were confirmed [23]. Before bacterial experiments, bacterial isolates were refreshed on nutrient agar (Oxoid, England) from the stocks. Mueller Hinton Broth (MHB) (Oxoid, England), Mueller Hinton agar (MHA) (Oxoid, England), tetracycline (Adco) were used in the present study. The antibacterial activity was carried out at Microbiology laboratory, College of Pharmacy, Najran University.

\section{Estimation of MICs and MBCs for AgNPs and tetracycline}

The MICs and MBCs of AgNPs synthesized by various plant extracts and tetracycline were determined by macrodilution broth method given by Clinical and Laboratory Standards Institute guidelines [24] using test tube preparation. The isolated bacteria, $S$. aureus and $K$. peumoniae were inoculated into Mueller Hinton broth medium and incubated at $37^{\circ} \mathrm{C}$ for 4 hours. Two-fold serial dilution of AgNPs and tetracycline at concentrations [100, 50, 25, 12.5, $6.25,3.12,1.6,0.78$ and $0.39 \mu \mathrm{g} / \mathrm{mL}$ ] were done using Mueller-Hinton Broth medium. From each microbe, $25 \mu \mathrm{L}$ inoculums at a concentration of $1.5 \times 106 \mathrm{CFU} / \mathrm{mL}$ [corresponding to 0.5 McFarland turbidity standards] was added to each test tube. The test tubes were incubated for 24 hours. at $37^{\circ} \mathrm{C}$. The lowest concentration that inhibited the microbial growth was taken as MIC. A loopful was taken from test tubes showing no visible growth, streaked onto MHA plates and incubated for 24 hours. at $37^{\circ} \mathrm{C}$. The least concentration without any bacterial growth was taken as MBC. Positive control experiments were performed using the bacterial isolate in the broth medium. Negative control tubes just contained MHB. The MIC and $\mathrm{MBC}$ for each strain was carried out in triplicate.

\section{Assessment of the individual and synergistic effects of AgNPs and tetracycline.}

In this study, S. aureus and $K$. pneumonia were subjected to individual and combined treatment with AgNPs and tetracycline. An agar disc diffusion assay was done on MHA as described previously $[25,26]$ with some modification and based on Clinical and Laboratory Standards Institute guidelines [27]. The microbes were inoculated into MHB and incubated at $37^{\circ} \mathrm{C}$ for 4 hours and matched to $0.5 \mathrm{McF}$ arland turbidity standards. The dried entire surface of MHA plates were inoculated with the two pathogenic bacteria using sterile swabs. $6 \mathrm{~mm}$ diameter sterile paper discs made of Whatman filter paper No. 1 loaded with $25 \mu \mathrm{L}$ of AgNPs $(100 \mu \mathrm{g} / \mathrm{mL})$ synthesized by different extracts, standard tetracycline discs and standard tetracycline disc loaded with $25 \mu \mathrm{L}$ of AgNPs $(100 \mu \mathrm{g} / \mathrm{mL})$ were placed and gently pressed on the surface of the inoculated plates. Filter paper discs loaded with sterile normal saline was used as negative control. The plates were incubated at $37^{\circ} \mathrm{C}$ for 24 hours and the zone of inhibition [ZOI] was measured in terms of millimeter using a ruler. These assays were carried out in triplicate. The increase fold in the antimicrobial activity and synergistic effects of AgNPs and tetracycline against tested bacteria was assessed using the formula: $b$ $-\mathrm{a} / \mathrm{a} \times 100$ where [b] is the ZOI of tetracycline with AgNPs and [a] is the ZOI of tetracycline respectively.

\section{Statistical analysis}

The results of individual and combined effects of AgNPs synthesized by various plant extracts and tetracycline on $S$. aureus and $K$. pneumoniae were expressed as means \pm S.E. [Standard Error]. The differences between means were analyzed statistically using analysis of variance [ANOVA] according to Tukey's HSD test via Statistical Package for the Social 
Sciences [SPSS] 15.0 software package in Microsoft Windows 7.0 operating system. The differences were considered statistically significant when $p \leq 0.05$.

\section{RESULTS AND DISCUSSION}

\section{Optimization of silver nanoparticles}

The aqueous plant extract was added to silver ions and the change of color was monitored. Formation of brown color indicated the ability of plant extract for biological reduction and capping of silver ions and synthesis of AgNPs due to excitation of surface plasmon vibrations (Fig.2). The bio-reduction rate of silver ions was increased by incubation the mixture at $37^{\circ} \mathrm{C}$ for 48 hours. These findings were coincided with the results previously observed [28, 29]. Among the different parameters and conditions tested, no change of color was detected by using either arak or mint extracts for biological reduction of AgNO3. These findings were contradicted with the results previously reported [30-33]. The phytochemical content of each plant might differ from region to another due to differences in the soil nutritive value and other environmental factors that affects the ability of plant extract to reduce metallic ions. Sidr leaves extract reduced the metal ions under all parameters used and the absorbance peak was detected by UV-Vis Spectrophotometer analysis. Similar finding has been reported in previous studies [34-36]. Garlic extract at concentrations [20, $25 \mathrm{gm} / 100$ distilled water], boiling for $5-10$ minutes, added at a percentage of $10 \mathrm{~mL} / 90 \mathrm{~mL}$ aqueous silver ions, molar silver ion concentration [1 $\mathrm{mM}, 2 \mathrm{mM}]$ gave yellowish to faint brown color after incubation for 48 hours. The resulting mixture was tested by using UV-Vis Spectrophotometer analysis; no surface plasmon resonance peak in absorption spectra was obtained. Component of garlic extract served as capping and reducing agents in the synthesis of AgNPs [37, 38]. Onion extract at concentrations [20, $25 \mathrm{gm} / 100$ distilled water], boiling for 5-10 minutes, added at a percentage of $10 \mathrm{~mL} / 90 \mathrm{~mL}$ aqueous silver ions and molar silver ion concentration [1 $\mathrm{mM}, 2 \mathrm{mM}]$ reduced the silver ions and the results were confirmed. These findings were supported by the results previously reported [39, 40]. Ginger extract at concentrations [20 gm/ 100 distilled water], boiling for 5-10 minutes, added at a percentage of $10 \mathrm{~mL} / 90 \mathrm{~mL}$ aqueous silver ions and molar silver ion concentration [1mM]supported the biological reduction of silver nitrate solutions in which the color of the mixture changed into brown and the results were confirmed by using UV-Vis Spectrophotometer. The best results for synthesis of AgNPs were obtained by ginger, sidr and onion extracts at these parameters: concentrations [20 gm/ 100 distilled water], boiling for 5 minutes, added at a percentage of $10 \mathrm{~mL} / 90 \mathrm{~mL}$ aqueous silver ions and $1 \mathrm{mM}$ silver ion concentration and incubated at $37^{\circ} \mathrm{C}$ for 48 hours. The synthesized AgNPs at the best parameters was characterized and used in the current study. Plant extracts contain wide range of metabolites such as alkaloids, carbohydrates, phenolic compounds, terpenoids, oxalic acid, ascorbic acid, enzymes and other reducing components like phenyl- propanoids. Various plant species and plant parts were successfully used for AgNPs synthesis. Biologically synthesized nanoparticles exclude the need for a capping and stabilizing agent and display shape and size-dependent biological activities. Stages of the green biosynthesis of silver nanoparticles from plant extracts during the chemical reaction included nucleation, condensation, surface reduction and stabilization [41-43].

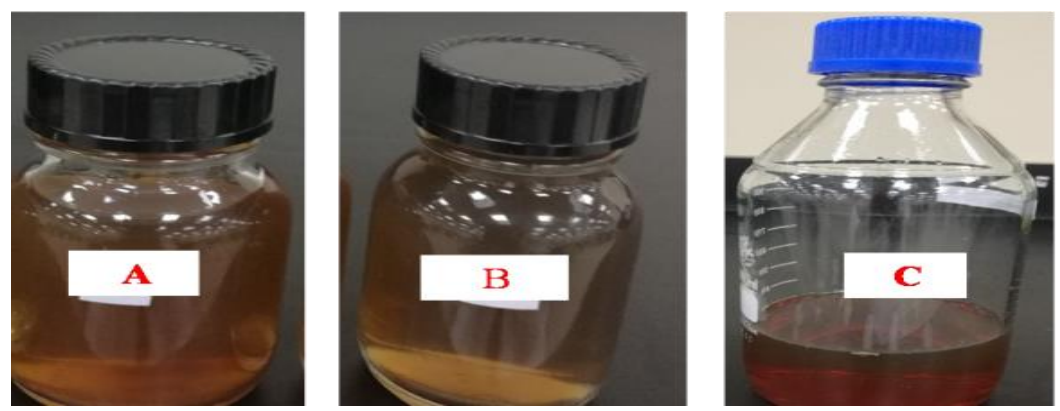

Figure 2. Biologically synthesized silver nanoparticles using plant extracts (A) AgNPs using ginger extract; (B) AgNPs using onion extract; (C) AgNPs using sidr extract. 


\section{Structural and morphological analysis of as-synthesized AGNPS}

Generally, the biosynthesized nanoparticles are characterized for their size, shape and dispersity [44]. Particles homogeneity, mono-dispersity with tiny sizes and extremely large surface area are among the required characteristics that would be important in several practical applications. The common techniques applied in this study for characterizing the bio-synthesized AgNPs are the UV-visible spectrophotometry, powder X-ray diffraction (XRD), scanning electron microscopy (SEM) and energy dispersive spectroscopy (EDS), Fourier transform infrared spectroscopy (FTIR) and Raman spectroscopy. Firstly, the bio-reduction of silver nanoparticles (AgNPs) using the three different plant extracts was notably observed as a color change of the plant extract just after the exposure to AgNO3aqueous solution. In agreement with an earlier work [45], the bio-reduction started immediately with a visual color change from colorless AgNO3 solution to darkish brown, indicating the successful reduction of $\mathrm{Ag}+$ ions to metallic $\mathrm{Ag}$ (I) NPs. The bio-reduction process was further examined using the UV-visible spectra measurements. The UV-vis spectra of produced AgNPs using the three different plant extracts along with the spectrum of $\mathrm{Ag}+$ ions as a control are displayed in Figure 3. Noticeable broad surface plasmon resonance (SPR) absorption peaks extending from 350-500 nm and centered at around 435 $\mathrm{nm}$ are detected in case of sidr and ginger plant extracts. Those absorption bands are related to the dipole resonance of conducting electrons on the surface of AgNPs. Those SPR peaks resemble to the absorption peak of AgNPs recently synthesized using a coffee extract [29]. However, in case of using onion plant extract, an absorption band located at a shorter wavelength $(\sim 360 \mathrm{~nm})$ is observed. Furthermore, the inset UV-vis spectrum is attributed to the blank $\mathrm{Ag}+$ ions without extracts, in which an absorption band is detected at $\sim 290 \mathrm{~nm}$. The formation of the two SPR peaks at $435 \mathrm{~nm}$, with the absence of $290 \mathrm{~nm}$ band is a direct evidence of the bio-reduction and formation of AgNPs using either sidr or ginger plant extracts. The higher peak intensity detected in case of sidr plant compared to ginger suggests its relatively stronger reducing power. It is worthy to mention that the characteristic SPR peak related to the reduced AgNPs has been reported to predominantly appear within the range between $400-500 \mathrm{~nm}[46,47]$. Now, a question arises to understand the formation of relatively small absorbance band at shorter wavelength of $360 \mathrm{~nm}$ in case of onion extract. Firstly, it has been reported that the electronic transitions of metallic AgOusually appear in the spectral range of $250-330 \mathrm{~nm}$ [48], i.e. at a shorter wavelength of SPR-related bands. Secondly, it is worthy to note that the absorption band of AgNPs would shift either to longer or shorter wavelength depending on the shape of the produced NPs and the surrounding environment $[49,50]$. Therefore, in case of onion plant extract and according to experimental observation, it is suggested that the band appeared at $360 \mathrm{~nm}$ is either due to the formed particles become more spherical 50 or owing to the presence of onion moieties. Additionally, the small band intensity reveals its lower reducing power compared to either sidr or ginger extracts.

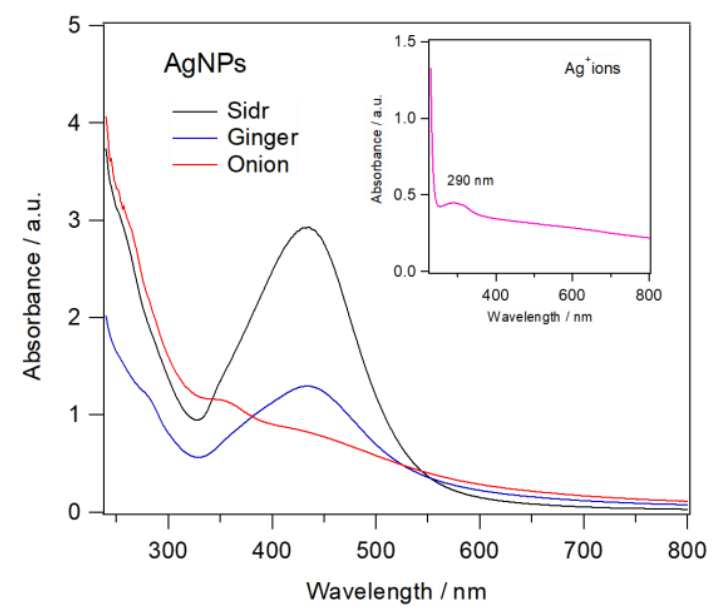

Figure 3. UV-vis spectra of AgNPs biosynthesized using three different plant extracts. The inset shows the absorbance spectrum of starting $\mathrm{Ag}+$ ions without reduction. 
The XRD analyses were performed to confirm the crystalline structure of the bio-synthesized NPs. The XRD patterns of as-synthesized AgNPs using the three tested plant extracts are shown in Figure 4. As could be revealed, all biosynthesized NPs showed typical four characteristic reflection peaks for the face-centered cubic metallic Ag at $2 \theta$ of $38.2^{\circ}, 44.3^{\circ}, 64.4^{\circ}$ and $77.4^{\circ}$, corresponding respectively to (111), (200), (220) and (311) facets of $\mathrm{Ag}$ (JCPDS No. 87-0717) [51].The intensity of the Ag-related peaks in the diffraction patterns is in the order; sidr extract > ginger>onion, in a good agreement with the above UV-vis spectral results.

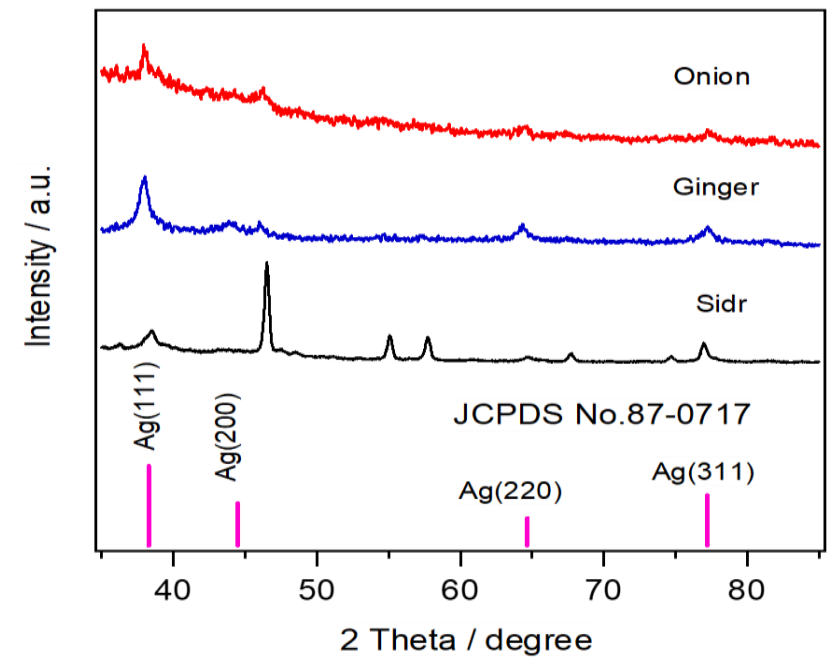

Figure 4. XRD patterns of biosynthesized AgNPs using three different plant extracts.

The produced AgNPs were visualized by SEM (Fig.5), which indicated that the as-synthesized AgNPs using the three plant extracts have spherical shapes capped with the bio-moieties. According to SEM micrographs, the mono-dispersity of the NPs is in the order of; ginger>sidr>onion extract. Based on image analysis, the average particle size was found to be15-25 nm for ginger, 30-60 nm for sidr and 50-120 nm for onion extract. The AgNPs are almost separated from each other, with relatively agglomerates formed in case of onion extract (image 5C). The more spherical particles observed for onion extract would explain the shift in the UV-vis absorption band to shorter wavelength shown above in Figure 5 [50]. The EDS spectrum (Fig.5 D) reveals strong spectral signal in the Ag region, which further confirmed the formation of AgNPs. The AgNPs typically exhibit optical absorption peak at approximately $3 \mathrm{KeV}$ due to the SPR [51].

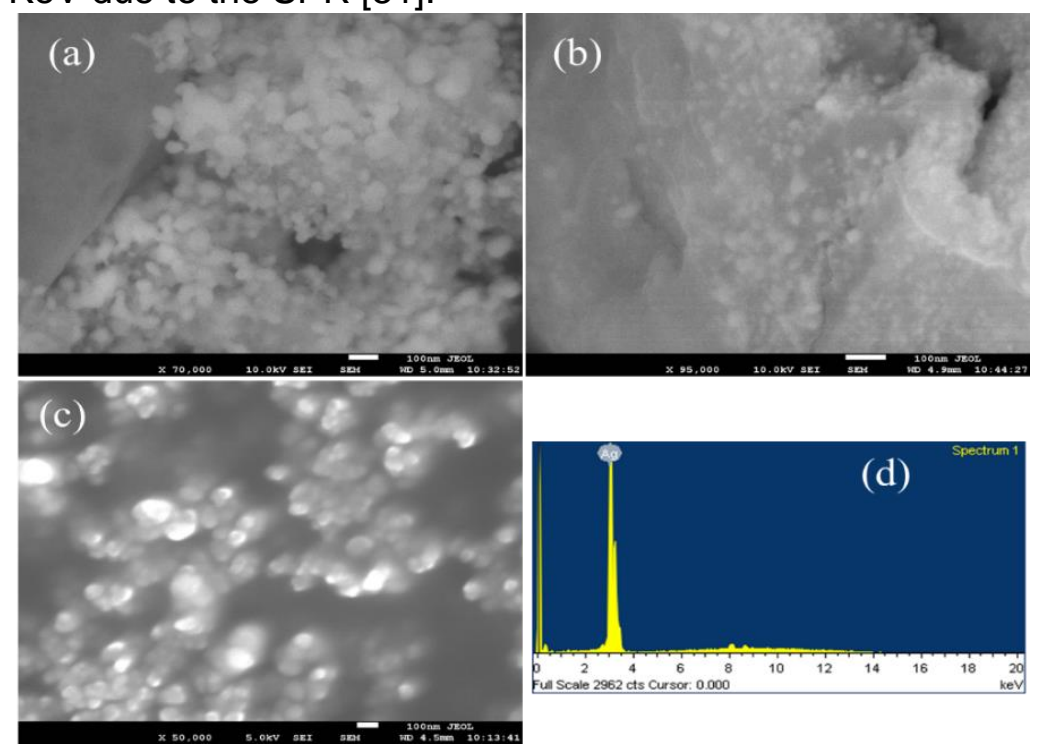

Figure 5. FE-SEM images of AgNPs biosynthesized using three different plant extracts; sidr extract (a), ginger extract (b), onion extract (c). The corresponding EDS analysis is shown in (d). 
FTIR measurements were performed to identify the functional groups present in the biomolecules leading to the bioreduction of $\mathrm{Ag}+$ and help capping the as-formed AgNPs. The FTIR spectra specially in case of sidr plant extract exhibited main absorption bands at 3420, 2923, 2857, 1730, 1634, 1440, 1376, 1243, 1042 and $602 \mathrm{~cm}-1$, (Fig.6), indicating the presence of residual capping agent with the AgNPs. The broad bands observed at $3420 \mathrm{~cm}-1$ in the spectra of both (sidr and ginger extracts) correspond to the $\mathrm{O}-\mathrm{H}$ stretching vibration indicating the presence of alcohol and phenolic-related species. The two bands detected at 2923 and $2857 \mathrm{~cm}-1$ are related to the $\mathrm{C}-\mathrm{H}$ stretching of aromatic compound. The small band at $1740 \mathrm{~cm}-1$ was only observed for sidr extract and can be assigned to the non-conjugated $\mathrm{C}-\mathrm{C}$ stretching. The strong bands appeared at $1634 \mathrm{~cm}-1$ in all plant extracts correspond to the $\mathrm{C}-\mathrm{N}$ and $\mathrm{C}-\mathrm{C}$ stretching vibration, suggesting the presence of proteins [52]. The band at $1440 \mathrm{~cm}-1$ could be assigned to the $\mathrm{N}-\mathrm{H}$ stretch vibration of amide moieties [53]. Appreciable stretch vibrational bands at $1042 \mathrm{~cm}-1$ detected in all plant extracts would be related to the $\mathrm{C}-\mathrm{O}-\mathrm{C}$ stretch of aromatic ethers and polysaccharides [54].Such detected functional groups would likely play a decisive role of both capping and stabilizing the as-formed AgNPs as has been reported in previous investigations [52, 55].The bands appeared at around $1376 \mathrm{~cm}-1$ typically represent the $\mathrm{N}=\mathrm{O}$ symmetry stretching of nitro-compound. The band observed at $1243 \mathrm{~cm}-1$ is attributed to the $\mathrm{C}-\mathrm{N}$ stretching of amines [53]. The bands located at 900-600 cm-1 region are connected to the $-\mathrm{NH} 2$ wagging of primary and secondary amines and amides [56]. In addition to the above band assignments, the band around $588 \mathrm{~cm}-1$ affirms the existence of AgNPs [57]. It can be concluded from the FTIR spectroscopic observation that the AgNPs surface is likely covered by organic species derived from the plant extracts.

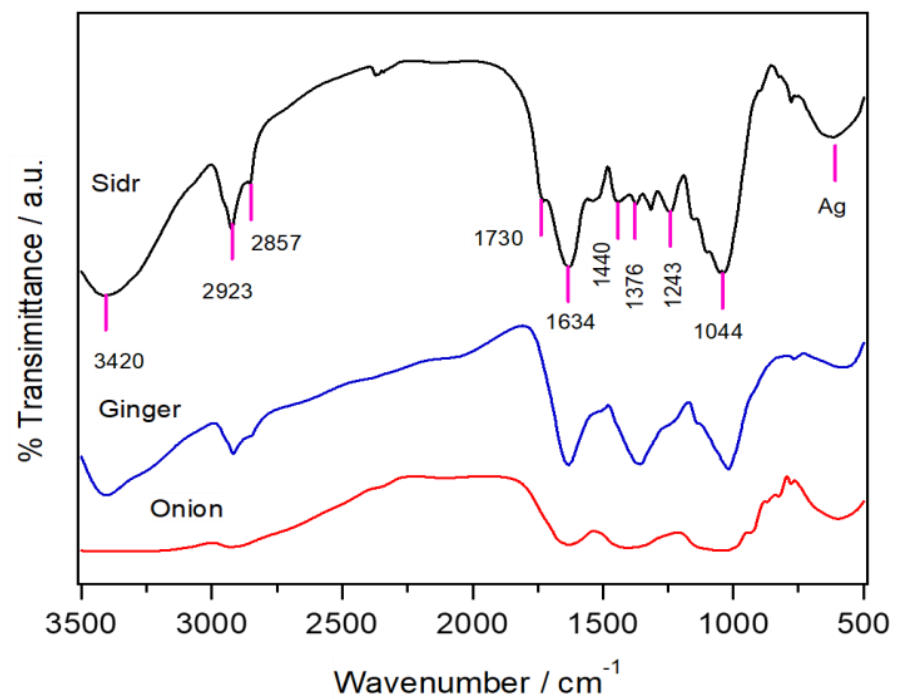

Figure 6. FTIR spectra of AgNPs biosynthesized by three different plant extracts.

\section{ANTIBACTERIAL ACTIVITY}

\section{Estimation of MICs and MBCs for AgNPs and tetracycline}

The MIC and MBC values of AgNPs synthesized by various plant extracts and tetracycline for tested microorganisms were listed in Table 1. The present findings revealed that silver nanoparticles prepared by ginger, onion and sidr extracts showed similar MIC and MBC towards $S$. aureus and $K$. pneumoniae $(100 \mu \mathrm{g} / \mathrm{mL})$. Our findings agree with other observations $[22,58]$. The MIC of tetracycline against $S$. aureus was $0.78 \mu \mathrm{g} / \mathrm{mL}$ while the $\mathrm{MBC}$ was $1.56 \mu \mathrm{g} / \mathrm{mL}$. The MIC and MBC of tetracycline for K. pneumoniae were $>100 \mu \mathrm{g} /$ $\mathrm{mL}$. These results contradicted with those reported in Refs. [59, 60]. 
Table 1: MIC and MBC of tetracycline and silver nanoparticles against $S$. aureus and K. pneumoniae.

\begin{tabular}{lcccc}
\hline Antibacterial & \multicolumn{2}{c}{ S. aureus } & \multicolumn{2}{c}{ K. pneumoniae } \\
\cline { 2 - 5 } agents & $\mathrm{MIC}(\mu \mathrm{g} / \mathrm{mL})$ & $\mathrm{MBC}(\mu \mathrm{g} / \mathrm{mL})$ & $\mathrm{MIC}(\mu \mathrm{g} / \mathrm{mL})$ & $\mathrm{MBC}(\mu \mathrm{g} / \mathrm{mL})$ \\
$\begin{array}{l}\text { Tetracycline } \\
\text { AgNPs using }\end{array}$ & 0.78 & 1.56 & $>100$ & $>100$ \\
$\begin{array}{l}\text { ginger extract } \\
\text { AgNPs using }\end{array}$ & 100 & 100 & 100 & 100 \\
$\begin{array}{l}\text { onion extract } \\
\text { AgNPs using }\end{array}$ & 100 & 100 & 100 & 100 \\
sidr extract & 100 & 100 & 100 & 100 \\
\hline
\end{tabular}

${ }^{*} \mathrm{MIC}$, minimum inhibitory concentration; MBC, minimum bactericidal concentration

\section{Assessment of the individual and synergistic effects of AgNPs and tetracycline.}

The individual and synergistic or additive antibacterial effects of AgNPs and tetracycline against tested bacteria were evaluated using the disc diffusion method. As shown in Table 2, the results showed that silver nanoparticles exhibited significant growth inhibitory effects $(p \leq 0.05)$ against $S$. aureus and $K$. pneumoniae. The ZOI of silver nanoparticles synthesized by sidr, onion and ginger extracts against $S$. aureus were $11.67 \pm 0.33 \mathrm{~mm}, 9.67 \pm 0.33 \mathrm{~mm}$ and $13.0 \pm 0.0 \mathrm{~mm}$ and for $K$. pneumoniae were $8.67 \pm 0.33 \mathrm{~mm}, 8.33 \pm 0.33 \mathrm{~mm}$ and $10.33 \pm 0.33 \mathrm{~mm}$ respectively. Our results agree with previous studies [22, 28, 61]. Rodríguez-León et al., (2013) [62] believed that the positive charge ions from silver nanoparticles were attached to the negative charge bacterial cell wall leading to its rupture, denaturation of proteins and finally cell death. Baker et al., (2017) [63] mentioned that AgNPs attach to the bacterial cell membrane, then enter to the bacteria and interact with the DNA and proteins resulting in bacterial cell death. Niraimathi et al., (2013) [55] proposed that the mechanism of action of AgNPs involves the conjugation of silver with oxygen and its reaction with sulfhydryl $[-\mathrm{S}-\mathrm{H}]$ groups on the cell wall to form $\mathrm{R}-\mathrm{S}-\mathrm{S}-\mathrm{R}$ bonds, causing cell death due to blocking respiration. Silver nanoparticles exhibit disturbance of the outer membrane and rupture of the cytoplasmic membrane, resulting depletion of intracellular ATP. AgNPs have antibacterial effects on Gram-negative bacteria, causing "pits" in the cell wall [64]. S. aureus was sensitive to tetracycline with ZOI $30.67 \pm 0.33 \mathrm{~mm}$. Tetracycline did not display any antimicrobial effects on $K$. pneumoniae with ZOI $0.0 \pm 0.00 \mathrm{~mm}$. The combined effect of tetracycline with AgNPs was assessed in comparison to tetracycline alone. The antibacterial activity of tetracycline increased in combination with AgNPs synthesized by various plant extracts, against $S$. aureus and $K$. pneumoniae. The percentage of the increased fold of tetracycline with AgNPs against $S$. aureus ranged from $12 \%-21 \%$. The combination of tetracycline with AgNPs prepared by sidr, onion and ginger extracts against $K$. pneumoniae significantly increased $(p \leq 0.05)$ the $Z O I$ from $0.0 \pm 0.00 \mathrm{~mm}$ to $11.67 \pm 0.33 \mathrm{~mm}, 10.67 \pm 0.33 \mathrm{~mm}$ and12.33 $\pm 0.33 \mathrm{~mm}$ respectively. Synergism between antibiotics and AgNPs has been documented in earlier reports [25, 26, 63]. Sangili and Gurunathan, (2015) [22] stated that Ag+ enhances the bactericidal activity of antibiotics by increasing the generation of reactive oxygen species that leads to death of the bacterial cell. Conjugation of antibiotic with AgNPs was effective against resistant bacteria [21]. Silver nanoparticles biologically synthesized by ginger gave the highest individual and combined activity against tested strains. Bactericidal effect of AgNPs are influenced by the particles size, the smaller the particles, the greater the antibacterial efficacy [65]. 
Table 2: Determination of the individual and combined effects of AgNPs and tetracycline against $S$. aureus and K. pneumoniae using disc diffusion method.

\begin{tabular}{|c|c|c|c|c|c|c|c|c|c|c|c|c|}
\hline \multirow{2}{*}{$\begin{array}{l}\text { Bacterial } \\
\text { species }\end{array}$} & \multicolumn{4}{|c|}{ AgNPs using sidr extract } & \multicolumn{4}{|c|}{ AgNPs using onion extract } & \multicolumn{4}{|c|}{ AgNPs using ginger extract } \\
\hline & S & AgNPs & TE & $\begin{array}{l}\text { TE+ } \\
\text { AgNPS }\end{array}$ & $\mathrm{S}$ & AgNPs & TE & $\begin{array}{l}\text { TE+ } \\
\text { AgNPS }\end{array}$ & $\mathbf{S}$ & AgNPs & TE & $\begin{array}{l}\text { TE+ } \\
\text { AgNPS }\end{array}$ \\
\hline S. aureus & $\begin{array}{l}00.00 \\
\pm .00^{\mathrm{a}}\end{array}$ & $\begin{array}{l}11.67 \\
\pm 0.33^{\text {ef }}\end{array}$ & $\begin{array}{l}33.33 \\
\pm 0.33^{h}\end{array}$ & $\begin{array}{l}38.00 \\
\pm 0.58^{i}\end{array}$ & $\begin{array}{l}00.00 \\
\pm .00^{a}\end{array}$ & $\begin{array}{l}9.67 \\
\pm 0.33^{\text {cd }}\end{array}$ & $\begin{array}{l}33.33 \\
\pm 0.33\end{array}$ & $\begin{array}{l}37.33 \\
\pm 0.33^{i}\end{array}$ & $\begin{array}{l}00.00 \\
\pm .00^{\mathrm{a}}\end{array}$ & $\begin{array}{l}13.0^{ \pm} \\
0.0^{g}\end{array}$ & $\begin{array}{l}33.33 \\
\pm 0.33^{h}\end{array}$ & $\begin{array}{l}40.33 \\
\pm 0.33^{i}\end{array}$ \\
\hline $\begin{array}{l}\text { K. } \\
\text { pneumoniae }\end{array}$ & $\begin{array}{l}00.00 \\
\pm .00^{\mathrm{a}}\end{array}$ & $\begin{array}{l}8.67 \\
\pm 0.33^{\text {bc }}\end{array}$ & $\begin{array}{l}00.00 \\
\pm .00^{\mathrm{a}}\end{array}$ & $\begin{array}{l}11.67 \\
\pm 0.33^{\text {ef }}\end{array}$ & $\begin{array}{l}00.00 \\
\pm .00^{\mathrm{a}}\end{array}$ & $\begin{array}{l}8.33 \\
\pm 0.33^{b}\end{array}$ & $\begin{array}{l}00.00 \\
\pm .00^{\mathrm{a}}\end{array}$ & $\begin{array}{l}10.67 \\
\pm 0.33 \text { de }\end{array}$ & $\begin{array}{l}00.00 \\
\pm .00^{\mathrm{a}}\end{array}$ & $\begin{array}{l}10.33 \\
\pm 0.33^{d}\end{array}$ & $\begin{array}{l}00.00 \\
\pm .00^{\mathrm{a}}\end{array}$ & $\begin{array}{l}12.33 \\
\pm 0.33^{\mathrm{fg}}\end{array}$ \\
\hline F- value & \multicolumn{12}{|c|}{2813.739} \\
\hline
\end{tabular}

S: normal saline; AgNPs: silver nanoparticles; TE: tetracycline. ${ }^{*}$ Values are the mean of three replicates \pm S.E. ${ }^{* *}$ In the same column, means followed by the same letters are not significantly different $(p \leq 0.05)$ as analyzed by Tukey's HSD test. F-value is significant at $p \leq 0.001$

\section{CONCLUSION}

The present study concluded that ginger, onion and sidr extracts converted silver ions to AgNPs. Arak, garlic and mint did not support silver nanoparticles formation. Synthesized silver nanoparticles were characterized using UV-Vis Spectrophotometer, FE-SEM, XRD, EDX and FTIR spectroscopy analysis. AgNPs prepared by different plant extracts exhibited antibacterial effects against the tested microorganism. Silver nanoparticles synthesized by ginger showed the highest individual and combined activity against $\mathrm{S}$. aureus and $\mathrm{K}$. pneumoniae followed by AgNPs prepared by sidr then that synthesized by onion. AgNPs prepared by various plant extracts enhanced the antibacterial efficacy of tetracycline against the tested microorganisms.

Funding: This study was funded by Deanship of Scientific Research, Najran University, Kingdom of Saudi Arabia (Grant Code No.: NU/MID/15/016). The support was provided in the form of materials and equipment required for conducting the research.

Acknowledgments: The authors thank Deanship of Scientific Research, Najran University, Saudi Arabia for its financial support of this study. The authors would like to thank Prof. Mohammed Ammar of Najran University for helping in data statistical analysis.

Conflicts of interest: The authors declare that they have no conflict of interests.

\section{REFERENCES}

1. Vandenesch F, Naimi T, Enright MC, Lina G, Nimmo GR, Heffernan H, et al. Community-acquired methicillin-resistant Staphylococcus aureus carrying Panton-Valentine leukocidin genes: worldwide emergence. Emerg Infect Dis. 2003;9:978-84.

2. Boucher HW, Talbot GH, Bradley JS, Edwards JE, Gilbert D, Rice LB, et al. Bad bugs, no drugs: no ESKAPE! an update from the infectious diseases society of America. Clin Infect Dis. 2009;48:1-12.

3. Iwase T, Uehara Y, Shinji H, Tajima A, Seo H, Takada K, et al. Staphylococcus epidermidis Esp inhibits Staphylococcus aureus biofilm formation and nasal colonization. Nature. 2010;465:346-9.

4. Walsh FM, Amyes SGB. Microbiology and drug resistance mechanisms of fully resistant pathogens, Curr Opin Microbiol. 2004;7:439-44.

5. Weinstein RA. Controlling antimicrobial resistance in hospitals: infection control and use of antibiotics. Emerg Infect Dis. 2001;7:188-92.

6. Tiller JC, Liao CJ, Lewis K, Klibanov AM. Designing surfaces that kill bacteria on contact. Proc Natl Acad Sci. 2001;98:5981-5. 
7. Stoimenov PK, Klinger RL, Marchin GL, Klabunde KJ. Metal oxide nanoparticles as bactericidal agents. Langmuir. 2002;18:6679-86.

8. Comfort KK, Maurer El, Braydich-Stolle LK, Hussain SM. Interference of Silver, Gold, and Iron Oxide Nanoparticles on Epidermal Growth Factor Signal Transduction in Epithelial Cells. ACS Nano. 2011;5:10000-8.

9. Mahmoudi M Serpooshan V. Silver-Coated Engineered Magnetic Nanoparticles Are Promising for the Success in the Fight against Antibacterial Resistance Threat. ACS Nano. 2012;6:2656-64.

10. Ocsoy I, Paret ML, Ocsoy MA, Kunwar S, Chen T, You M, et al. Nanotechnology in Plant Disease Management DNA-Directed Silver Nanoparticles on Graphene Oxide as anAntibacterial against Xanthomonasperforans. ACS Nano. 2013;7:8972-80.

11. Stensberg MC, Wei Q, McLamore ES, Porterfield DM, Wei A, Sepúlveda MS. Toxicological studies on silver nanoparticles: challenges and opportunities in assessment, monitoring and imaging. Nanomedicine. 2011;6(5):879-98.

12. Matsumura Y, Yoshikata K, Kunisaki S, Tsuchido T. Mode of Bactericidal Action of Silver Zeolite and Its Comparison with That of Silver Nitrate. Appl Environ Microbiol. 2003; 69(7): 4278-4281.

13. Parashar UK, Saxena PS, Srivastava A. Bioinspired synthesis of silver nanoparticles. Dig J Nanomater Biostruct. 2009;4(1):159-66.

14. Parashar V, Parashar R, Sharma B, Pandey AC. Partenium leaf extract mediated synthesis of silver nanoparticles: a novel approach towards weed utilization. Dig J Nanomater Biostruct. 2009;4(1):45-50.

15. Li S, Shen Y, Xie A, Yu X, Qiu L, Zhang L, et al. Green synthesis of silver nanoparticles using Capsicum annum L, Extract. Green Chem. 2007;9(8):852-58.

16. Shankar SS, Ahmad A, Sastry M. Geranium leaf assisted biosynthesis of silver nanoparticles. Biotechnol Prog. 2003;19(6):1627-31.

17. Bhattacharya SK. National Institute of Cholera and Enteric Diseases. An evaluation of current cholera treatment. Expert Opin Pharmacother. 2003;4(2):141-6.

18. Parsi VK. Cholera Prim Care Update Ob Gyns. 2001;8(3):106-9.

19. Fayaz AM, Balaji K, Girilal M, Yadav R, Kalaichelvan PT, Venketesan R. Biogenic synthesis of silver nanoparticles and their synergistic effect with antibiotics: a study against gram-positive and gram-negative bacteria. Nanomedicine. 2010;6(1):103-9.

20. Li P, Li J, Wu C, Wu Q, Li J. Synergistic antibacterial effects of antibiotic combined with silver nanoparticles. Nanotechnology. 2005;16(9):1912-7.

21. Allahverdiyev AM, Kon KV, Abamor ES, Bagirova M, Rafailovich M. Coping with antibiotic resistance: combining nanoparticles with antibiotics and other antimicrobial agents. Expert Rev Anti Infect Ther. 2011;9(11):1035-52.

22. Sangili $Y$, Gurunathan I. Biologically synthesized silver nanoparticles enhances antibiotic activity against Gram-negative bacteria. J Ind Eng Chem. 2015;29:217-26.

23. Koneman EW, Allen SD, Janda WM, Schreckenberger PC, Winn WC. Packaged in Kit Identification System. In: Color Atlas and Textbook of Diagnostic Microbiology. 4th ed. Koneman EW, editor. Philadelphia: B. Lippincott Co.; 1992; p. 163-170. 
24. Clinical and Laboratory Standards Institute. Methods for dilution antimicrobial susceptibility tests for bacteria that grow aerobically, approved standard. 10th Edition. CLSI document M07-A10. Wayne, Pennsylvania (USA); 2015.

25. Shahverdi AR, Fakhimi A, Shahverdi HR, Minaian S. Synthesis and effect of silver nanoparticles on the antibacterial activity of different antibiotics against Staphylococcus aureus and Escherichia coli. Nanomedicine: NBM. 2007;3:168 - 71.

26. Kora AJ, Rastogi L. Enhancement of Antibacterial Activity of Capped Silver Nanoparticles in Combination with Antibiotics, on Model Gram-Negative and Gram-Positive Bacteria. Bioinorg Chem Appl. 2013;871097:7.

27. Clinical and Laboratory Standards Institute. Performance standards for antimicrobial susceptibility testing: $21^{\text {st }}$ informational supplement, CLSI document M100 - S21. Wayne, PA: The Institute, CLSI; 2012.

28. Shalaby TT, Mahmoud OA, El Batouti GA, Ibrahim EE. Green synthesis of silver nanoparticles: synthesis, characterization and antibacterial activity. J Nanosci Nanotechnol. 2015;5(2):23-9.

29. Dhand V, Soumya L, Bharadwaj S, Chakra S, Bhatt D, Sreedhar B. Green synthesis of silver nanoparticles using Coffea Arabica seed extract and its antibacterial activity. Mater Sci Eng C. 2016;58:36-43.

30. Shaik MR, Albalawi GH, Khan ST, Khan M, Adil SF, Kuniyil M, et al. "Miswak" Based Green Synthesis of Silver Nanoparticles: Evaluation and Comparison of Their Microbicidal Activities with the Chemical Synthesis. Molecules. 2016;21(11):1478.

31. Fathi H, Ramedani S, Heidari D, Nejat HY, Habibpour M, Ebrahimnejad P. Green Synthesis of Silver Nanoparticles Using Mentha aquatic L Extract as the Reducing Agent. J. Kerman Univ. Med. Sci. 2017;24(1):28-37.

32. Alshaye NA, Elobeid MM, Alkhalifah DHM, Mohammed AE. Characterization of biogenic silver nanoparticles by salvadora persica leaves extract and its application against some MDR pathogens E. coli and S. aureus. Res J Microbiol. 2017;12:74-81.

33. Sarkar D, Paul G. Green Synthesis of Silver Nanoparticles using Mentha asiatica [Mint] Extract and Evaluation of their Antimicrobial Potential. Int J Curr Res Biosci Plant Biol. 2017;4(1):77-82.

34. Abdel-Fatah MA, Hussein NH, Hawash SI, Shaarawy HH. Investigation of using sidr leave extracts in nano-silver preparation. ARPN J Eng Appl Sci. 2016;11(19):11649-54.

35. Masoud EA, Al-Hajry AM, Al-Marrani A. Antibacterial Activity of Silver Nanoparticles Synthesized by Sidr [Ziziphus spina- Christi] Leaf Extract against Pathogenic Bacteria. Int J Curr Microbiol App Sci. 2016;5(4):226-36.

36. Halawani EM. Rapid Biosynthesis Method and Characterization of Silver Nanoparticles Using Ziziphus spina christi Leaf Extract and Their Antibacterial Efficacy in Therapeutic Application. J Biomater Nanobiotechnol. 2017; 8:22-35.

37. White GV, Kerscher P, Brown RM, Morella JD, McAllister W, Dean D, et al. Green Synthesis of Robust, Biocompatible Silver Nanoparticles Using Garlic Extract. J Nanomater. 2012; 730746:12.

38. Rajoriya P, Misra P, Shukla PK, Ramteke PW. Light-regulatory effect on the phytosynthesis of silver nanoparticles using aqueous extract of garlic [Allium sativum] and onion [Allium onion] bulb. Curr Sci. 2016;3(8):1364-8. 
39. Al-Kalifawi EJ, Al-Saadi TM, Al-Dulaimi SA, Al-Obodi EE. Biosynthesis of silver nanoparticles by using onion [Allium onion] extract and study antibacterial activity. J Genet Environ Resour Conserv. 2015;3(1):1-9.

40. Balamanikandan T, Balaji S, Pandiarajan J. Biological Synthesis of Silver Nanoparticles by Using Onion [Allium onion] Extract and Their Antibacterial and Antifungal Activity. World Appl Sci J. 2015;33(6):939-43.

41. Patil MP, Kim GD. Eco-friendly approach for nanoparticles synthesis and mechanism behind antibacterial activity of silver and anticancer activity of gold nanoparticles. Appl Microbiol Biotechnol. 2017;101(1):79-92.

42. Priyaa GH, Satyan KB. Biological Synthesis of Silver Nanoparticles using Ginger [Zingiber Ginger] Extract. J Environ Nanotechnol. 2014;3(4):32-40.

43. Velmurugan P, Anbalagan K, Manosathyadevan M, Lee KJ, Cho M, Lee SM, et al. Green synthesis of silver and gold nanoparticles using Zingiber ginger root extract and antibacterial activity of silver nanoparticles against food pathogens. Bioprocess Biosyst Eng. 2014;37(10):1935-43.

44. Jiang J, Oberdörster G, Biswas P. Characterization of size, surface charge, and agglomeration state of nanoparticle dispersions for toxicological studies. J Nanopart Res. 2009; 11:77-89.

45. Reiad NA, Abdel Salam OE, Abadir EF, Harraz FA. Green synthesis of antibacterial chitosan films loaded with silver nanoparticles. Chinese J Polym Sci. 2013;31(7):984-93.

46. Kaur G, Verma RK, Rai DK, Rai SB. Plasmon-enhanced luminescence of Sm complex using silver nanoparticles in polyvinyl alcohol. J Lumin. 2012; 132:1683-7.

47. Venugopal N, Mitra A. Influence of temperature dependent morphology on localized surface plasmon resonance in ultra-thin silver island films. Appl Surf Sci. 2013; 85:357-72.

48. Lu J, Bravo-Suárez JJ, Takahashi A, Haruta M, Oyama ST. In situ UV-vis studies of the effect of particle size on the epoxidation of ethylene and propylene on supported silver catalysts with molecular oxygen. J. Cataly. 2005;232(1):85-95.

49. Chakraborty P. Metal nanoclusters in glasses as non-linear photonic materials. J Mater Sci.1998; 33:2235-49.

50. Baia L, Baia M, Kiefer W, Popp J, Simon S. Structural and morphological properties of silver nanoparticles-phosphate glass composites. Chem Phys. 2006; 327:63-9.

51. Sun Y, Xia Y. Shape-controlled synthesis of gold and silver nanoparticles. Science. 2002;13;298(5601):2176-9.

52. Prakash P, Gnanaprakasam P, Emmanuel R, Arokiyaraj S, Saravanan M. Green synthesis of silver nanoparticles from leaf extract of Mimusopselengi, Linn. for enhanced antibacterial activity against multi drug resistant clinical isolates. Colloids Surf B Biointerfaces. 2013;1(108):255-9.

53. Jyoti $K$, Baunthiyal $M$, Singh, A. Characterization of silver nanoparticles synthesized using Urticadioica Linn. leaves and their synergistic effects with antibiotics. J Radiat Res Appl Sci. 2016;9(3):217-27.

54. Szymczycha-Madeja A, Welna M, Zyrnicki W. Multi-element analysis, bioavailability and fractionation of herbal tea products. J Brazil Chem Soc. 2013;24(5):777-87.

55. Niraimathi KL, Sudha V, Lavanya R, Brindha P. Biosynthesis of silver nanoparticles using Alternantherasessilis (Linn.) extract and their antimicrobial, antioxidant activities. Colloids Surf $B$ Biointerfaces. 2013;1(102):288-91. 
56. Rónavári A, Kovács $D$, Igaz N, Vágvölgyi $C$, Boros IM, Kónya $Z$, et al. Biological activity of green-synthesized silver nanoparticles depends on the applied natural extracts: a comprehensive study. Int J Nanomed. 2017;12:871-83.

57. Tripathi S, Mehrotra GK, Dutta PK. Chitosan-silver oxide nanocomposite film: preparation and antimicrobial activity. Bull Mater Sci. 2011;34(1):29-35.

58. Balakumaran MD, Ramachandran R, Balashanmugam P, Mukeshkumar DJ, Kalaichelvan PT. Mycosynthesis of silver and gold nanoparticles: Optimization, characterization and antimicrobial activity against human pathogens. Microbiol Res. 2016; 182:8-20.

59. Stock I, Wiedemann B. Natural antibiotic susceptibility of Klebsiella pneumoniae, K. oxytoca, $K$. planticola, K. ornithinolytica and K. terrigena strains. J Med Microbiol. 2001; 50:396-406.

60. Kowser MM, Hoque MM, Fatema N. Determination of MIC and MBC of selected tetracycline capsule commercially available in bangaladesh. Orion Med J. 2009;32(3):684-6.

61. Li WR, Xie XB, Shi QS, Zeng HY, Ou-Yang YS, Chen YB. Antibacterial activity and mechanism of silver nanoparticles on Escherichia coli. Appl Microbiol Biotechnol. 2010;85(4):1115-22.

62. Rodríguez-León E, Iñiguez-Palomares R, Navarro RE, Herrera-Urbina R, Tánori J, Iñiguez-Palomares $\mathrm{C}$, et al. Synthesis of silver Claudia nanoparticles using reducing agents obtained from natural sources (Rumex hymenosepalus extracts). Nanoscale Res Lett. 2013;8(1):318.

63. Baker S, Pasha A, Satish S. Biogenic nanoparticles bearing antibacterial activity and their synergistic effect with broad spectrum antibiotics: Emerging strategy to combat drug resistant pathogens. Saudi Pharm. J. 2017;25(1):44-51.

64. Zhang H, Wu M, Sen A. Silver Nanoparticle Antimicrobials and Related Materials. Cioffi, Nicola, Rai, Mahendra, editors. Nano-Antimicrobials Progress and Prospects; 2012. p. 3-45.

65. Baker C, Pradhan A, Pakstis L, Pochan DJ, Shah SI. Synthesis and antibacterial properties of silver nanoparticles. J Nanosci Nanotechnol. 2005;5(2):244-9.

(C) 2018 by the authors. Submitted for possible open access publication under the terms and conditions of the Creative Commons Attribution (CC BY NC) license (https://creativecommons.org/licenses/by-nc/4.0/). 